\title{
Farm Mortgagor Relief Legislation in Iowa During the Great Depression
}

\author{
PATRICK B. BAUER
}

ONE OF THE MOST PRESSING PROBLEMS facing Iowa during the Great Depression was the financial distress of farm mortgagors. From 1933 through 1939, the General Assembly enacted both temporary and permanent laws that delayed or cushioned the effects of mortgage foreclosure proceedings. A number of these mortgagor relief laws were challenged in the courts as violations of federal and state constitutional prohibitions of contract impairment, but the challenges generally were rejected in opinions that adopted a flexible view of the reach and scope of such prohibitions.

This paper's consideration of farm mortgagor relief legislation in Iowa during the 1930s begins with brief descriptions of some of the economic, legal, and political circumstances leading up to and surrounding the enactment of such legislation. The paper then examines the content and effects of individual mortgagor relief laws, judicial determinations of their validity and scope, and the general nature of complementary federal farm mortgagor relief programs. The paper concludes with an assessment of the effectiveness and significance of the farm mortgagor relief measures Iowa enacted during the Great Depression, and a brief outline of some of the parallel aspects of the farm mortgagor relief measures Iowa has enacted during the $1980 \mathrm{~s}$.

I gratefully acknowledge the able research assistance of Randall J. Ney, and the helpful suggestions generously provided by Christine M. Luzzie.

THE ANNALS OF IOWA 50 (Summer 1989). (CThe State Historical Society of Iowa, 1989. 
TABLE 1

IOWA Agricultural Economic Conditions, 1911-1940

\begin{tabular}{|c|c|c|c|c|}
\hline Year & $\begin{array}{c}\text { Iowa Farm } \\
\text { Products } \\
\text { Price Index } \\
(1910-14=100)^{a}\end{array}$ & $\begin{array}{l}\text { Average per } \\
\text { Acre Value } \\
\text { of Iowa } \\
\text { Farmland }^{\mathrm{b}}\end{array}$ & $\begin{array}{l}\text { Iowa Farm } \\
\text { Mortgage Loans } \\
\text { Outstanding } \\
\text { (millions } \\
\text { of dollars) }\end{array}$ & $\begin{array}{c}\text { Estimated } \\
\text { Number of } \\
\text { Iowa Farm } \\
\text { Foreclosures }^{\mathrm{d}}\end{array}$ \\
\hline 1911 & 86 & 100 & 484,300 & - \\
\hline 1912 & 100 & 104 & 546,708 & - \\
\hline 1913 & 104 & 108 & 595,272 & - \\
\hline 1914 & 108 & 113 & 659,801 & - \\
\hline 1915 & 102 & 121 & 717,919 & - \\
\hline 1916 & 121 & 137 & 792,700 & - \\
\hline 1917 & 186 & 143 & 888,231 & - \\
\hline 1918 & 212 & 155 & 986,643 & - \\
\hline 1919 & 221 & 171 & $1,066,535$ & - \\
\hline 1920 & 190 & 227 & $1,187,185$ & - \\
\hline 1921 & 109 & 210 & $1,503,660$ & - \\
\hline 1922 & 115 & 174 & $1,535,369$ & - \\
\hline 1923 & 115 & 168 & $1,535,943$ & - \\
\hline 1924 & 122 & 155 & $1,567,032$ & - \\
\hline 1925 & 150 & 149 & $1,479,538$ & - \\
\hline 1926 & 145 & 142 & $1,381,033$ & - \\
\hline 1927 & 138 & 132 & $1,279,838$ & 2,300 \\
\hline 1928 & 144 & 129 & $1,252,557$ & 1,900 \\
\hline 1929 & 147 & 128 & $1,249,233$ & 1,500 \\
\hline 1930 & 126 & 124 & $1,196,197$ & 1,500 \\
\hline 1931 & 87 & 109 & $1,142,778$ & 3,400 \\
\hline 1932 & 58 & 89 & $1,079,337$ & 6,400 \\
\hline 1933 & 58 & 65 & 982,484 & 3,700 \\
\hline 1934 & 78 & 70 & 862,440 & 4,100 \\
\hline 1935 & 118 & 73 & 787,159 & 2,000 \\
\hline 1936 & 119 & 79 & 750,163 & 1,450 \\
\hline 1937 & 133 & 79 & 721,657 & 1,375 \\
\hline 1938 & 107 & 80 & 700,729 & 620 \\
\hline 1939 & 96 & 79 & 684,751 & 1,895 \\
\hline 1940 & 98 & 79 & 657,868 & 500 \\
\hline
\end{tabular}

SOURCES:

apatrick B. Bauer, "Judicial Foreclosure and Statutory Redemption: The Soundness of Traditional Preference for Protection over Credit," Iowa Law Review 71 (October 1985), $85-86$.

blbid.

'Donald C. Horton, Harald C. Larsen, and Norman J. Wall, Farm-Mortgage Credit Faciliin the United States (Washington, DC, 1942), 219-21.

dWilliam G. Murray and Willard O. Brown, Farm Land and Debt Situation in Iowa, 1935 1935), 18; William G. Murray, Corporate Land, Foreclosures, Mortgage Debt and Land Valin Iowa, 1939 (Ames, 1939), 315; Robert H. Skilton, Government and the Mortgage Debtor to 1939) (Philadelphia, 1944), 109. 
THE FARM MORTGAGE PREDICAMENT confronting Iowa in the early 1930s was the culmination of a set of economic circumstances that had been unfolding since the outbreak of the First World War (see table 1). ${ }^{1}$ With a wartime surge in export demand, the prices commanded by Iowa farm products more than doubled between 1914 and 1919. The average price of Iowa farmland followed closely behind, and also had doubled by 1920 . These sharp increases in farm income and assets occasioned a like growth in farm mortgage indebtedness as more farmers encumbered their land with larger-sized loans. Most of the new mortgages financed purchases of farmland at advanced values, and secured debts owed to individuals and commercial banks. ${ }^{2}$

Farm product prices started to fall in 1920, and, after dropping in 1921 to a low that was less than half of the peak reached in 1919, increased only slightly through 1924 . Although this reduction in farm income triggered a relatively smaller and more gradual decline in farmland values, outstanding farm mortgage indebtedness continued to expand as renewals of existing debts frequently incorporated unpaid interest and operating expenses. While farm mortgage foreclosures climbed dramatically, many involved junior mortgages that could have been carried only at the levels of farm product prices and farmland values that had prevailed during the final years of the preceding boom. ${ }^{3}$

A modest improvement in farm product prices during the second half of the 1920s slowed the decline of farmland values, but farm mortgage foreclosures dropped off only slightly as the persistence of reduced farm income and asset values steadily exhausted the financial stamina of relatively more heavily indebted farmers. The viability of more modest-sized mort-

1. General descriptions of farm economic and political conditions in Iowa during the interwar period are provided by Leland L. Sage, "Rural Iowa in the 1920s and 1930s: Roots of the Farm Depression," Annals of Iowa 47 (Fall 1983), 91-103, and Joseph F. Wall, "The Iowa Farmer in Crisis, 1920-1936," Annals of Iowa 47 (Fall 1983), 116-27.

2. William G. Murray and Ronald C. Bentley, Iowa Farm Mortgage Situation (Ames, 1933), 46-47, 50-51, 52-54.

3. Ibid., 45, 50-51; idem, Farm Mortgage Foreclosures (Ames, 1933), 163-64, 166-67. 
gages, however, was affirmed throughout most of the 1920s by the willingness with which insurance companies and the recently established federal and joint stock land bank institutions refinanced many of the mortgages that had been held by individuals and banks at the outset of the decade. ${ }^{4}$

Toward the end of the 1920s, the nation as a whole began its slide into the Great Depression of the 1930s. Farm product prices fell more than 50 percent between 1930 and 1932, and almost as great a decline in farmland values had resulted by 1933. Farm mortgage foreclosures quadrupled, and in contrast to those of the 1920 s, these proceedings involved large numbers of first mortgages that previously would not have been regarded as imprudent. ${ }^{5}$

Iowa obviously could do little to change the national economic circumstances that had precipitated widespread farm mortgage foreclosures in the early 1930s. The incidence and extent of some of the burdens of foreclosures, however, were determined by the content and operation of the procedures for the enforcement of mortgages prescribed by state law.

The mortgage foreclosure procedures that existed in Iowa at the outset of the Great Depression had been in place since a previous episode of agricultural boom and bust during the late 1850s. ${ }^{6}$ Upon a mortgagor's failure to make a scheduled payment, the mortgagee could commence a judicial proceeding to obtain a judgment for the entire unpaid balance of the mortgage debt and a decree directing that the judgment initially be enforced by a sale of the mortgaged land. If the proceeds of the sale did not fully satisfy the judgment, the remaining "deficiency" could be enforced against other land or personal property the mortgagor might then own or thereafter acquire. At

4. William G. Murray, Farm Mortgage Foreclosures in Southern Iowa, 19151936 (Ames, 1938), 250-52; Murray and Bentley, Iowa Farm Mortgage Situation, 54; idem, Farm Mortgage Foreclosures, 164.

5. Murray and Bentley, Farm Mortgage Foreclosures, 164-66; Lowell K. Dyson, "Was Agricultural Distress in the 1930's a Result of Land Speculation During World War I? The Case of Iowa," Annals of Iowa 40 (Spring 1971), 577, 582.

6. Patrick B. Bauer, "Judicial Foreclosure and Statutory Redemption: The Soundness of Iowa's Traditional Preference for Protection over Credit," Iowa Law Review 71 (October 1985), 1, 29-42. 
any time during a one-year period following the sale, the mortgagor could regain ownership of the mortgaged land by "redeeming" it from the sale purchaser at the price for which it had been sold at the sale, and until the end of the same period, the mortgagor also was entitled to retain possession of the mortgaged land. ${ }^{7}$ The mortgagor's right of possession until the end of the redemption period, however, could be pledged as additional security for the mortgage debt. If a sale of the mortgaged land would not fully satisfy the mortgage debt, this additional security could be enforced through a receivership in which the rents and profits of the mortgaged land would be applied toward satisfaction of the deficiency. ${ }^{8}$

Although the content and operation of Iowa's mortgage foreclosure procedures could be changed by the General Assembly, the effect of such changes on previously executed mortgages was subject to federal and state prohibitions of contract impairment. Over the course of the nineteenth century, the federal constitutional provision that "No State shall ... pass any ... Law impairing the Obligation of Contracts" and the cognate Iowa provision that "No ... law impairing the obligation of contracts ... shall ever be passed" generally had been construed as rather unyielding barriers to any retrospective operation of changed procedures that were materially less favorable to mortgagees than the procedures that had existed when the mortgage was created. ${ }^{9}$ Occasionally, however, laws that rather clearly transgressed these standards had been enacted in an attempt to provide relief to mortgagors in the interval between the enactment of such laws and their invalidation by the courts. ${ }^{10}$

Although mortgagor relief legislation generally does not appear to have involved much partisan conflict, Democrats had

7. Iowa Code $\S \S 11659,11774,12372,12376,12377$ (1931) (current versions at Iowa Code $\S \S 626.12,628.3,654.1,654.5,654.6$ (1987)).

8. "Mortgage Receiverships in Iowa," Iowa Law Review 27 (May 1942), 626.

9. U.S. Const., Art I, §̧ 10; Iowa Const., Art. I, § 21; Benjamin F. Wright, The Contract Clause of the Constitution (Cambridge, MA, 1938), 68-71, 104-9. For illustrative Iowa cases, see Malony $v$. Fortune, 14 Iowa 417 (1862), and Rosier v. Hale, 10 Iowa 470 (1860).

10. Charles Warren, Bankruptcy in United States History (Cambridge, MA, 1935), 146-48. 
partial or complete control over all three branches of state government during most of the period in which such legislation was enacted and operated. ${ }^{11}$ In the 1932 election, Democratic candidates were elected to positions that had been held by an almost unbroken line of Republicans since before the Civil War. Clyde L. Herring became the first Democratic governor since Horace Boies in the early 1890 s, and for the first time since the tenure of LeVega G. Kinne during that same period, Democrats were elected to the four open seats on the supreme court. Democrats won more than two-thirds of the 108 seats in the House of Representatives, and while holdover seats left the Senate in a 25-25 tie, the Democrats had a nominal advantage because the presiding officer, Lieutenant Governor Nelson G. Kraschel, also was a Democrat. By considerably smaller margins, the Democrats again prevailed in the 1934 election. Governor Herring was reelected, and Democrats were elected to four more seats on the supreme court. The Democratic margin in the House of Representatives dropped to eight seats, but a four-seat margin was obtained in the Senate.

The receding of state government to the Republicans began in the 1936 election. The Democrats lost the Senate and fell to a 54-54 tie in the House of Representatives. Lieutenant Governor Kraschel, however, advanced to the governorship by a margin of fewer than 2,500 votes, and the last Republican seat on the supreme court was lost as Democrats were elected to all three open supreme court seats. In the 1938 election, the Republicans regained the governorship and recaptured commanding margins in both the Senate and the House of Representatives. Republicans also were elected to the four open seats on the supreme court, but staggered terms postponed a Republican majority until the 1940 election.

THE PROBLEMS OF FARM MORTGAGORS were conspicuous when Iowa's Forty-fifth General Assembly convened in Des Moines on January 9, 1933. Violence had occurred or

11. Statements concerning gubernatorial and judicial elections are based on Iowa Official Register (1933-34 through 1943-44), and statements concerning the General Assembly's partisan composition are based on Iowa Senate Journal (1933-1939) and Iowa House Journal (1933-1939). 
had been threatened at a number of foreclosure sales across the state. ${ }^{12}$ During the first week of the session, the outgoing and incoming governors both stressed the need for relief legislation in addresses to joint sessions of the General Assembly. In his farewell message on the condition of the state, Governor Turner urged that farm mortgagors be protected from foreclosure upon application of one-half of the crop to the payment of interest and taxes. ${ }^{13}$ Governor Herring's inaugural address also called for changes in mortgage foreclosure procedures, but cautioned that such measures would not fully solve Iowa's farm mortgage problems.

The great part of the program of the restoration of agriculture must be furnished by the national government by means adopted to restore the price level ... and by a method which will permit a better refinancing of farm debts....

We must do all in our power to give [the farmer] a chance to hold his farm pending relief by national legislation. To frame equitable legislation conforming to the constitutional requirements ... will take all the energy and legal skill that you can bring to it. ${ }^{14}$

The following week both the Senate and the House appointed special committees on emergency legislation. The committees met jointly to hear the views of farmer organizations, insurance companies, and banks. ${ }^{15}$ At the committees' request, on January 19 Governor Herring issued a proclamation calling for the immediate cessation of all efforts to enforce mortgages pending the consideration and enactment of appropriate relief legislation. ${ }^{16}$ The legal basis and effect of the proclamation were rather uncertain, but it apparently was honored by many mortgagees. ${ }^{17}$

12. Archibald M. Woodruff, Farm Mortgage Loans of Life Insurance Companies (New Haven, CT, 1937), 101-4; John L. Shover, Cornbelt Rebellion: The Farmers' Holiday Association (Urbana, IL, 1965), 77-81.

13. 1933 Iowa Senate Journal 41-42.

14. Ibid., 64-65.

15. Des Moines Register, 18 January 1933, 1.

16. Des Moines Register, 20 January 1933, 1.

17. In the days following its issuance, a number of life insurance companies 
The General Assembly enacted its first mortgagor relief law in early February. The law authorized the courts to grant continuances of mortgage foreclosure proceedings until March 1,1935 . The continuance had to be requested by the mortgagor, and could be denied for "good cause." During the term of the continuance, the court could allow the mortgagor to remain in possession of the mortgaged land upon the payment of a fair rent, which would be applied toward the payment of taxes, insurance, and other costs of maintenance and upkeep, with any balance being distributed "as the court [might] . . . direct." 18

Because the mortgage foreclosure continuance law applied only to pending and subsequently commenced foreclosure proceedings, it did not help mortgagors against whom decrees of foreclosure had already been entered. In mid-March, however, the General Assembly enacted a second law which authorized the courts to grant extensions of unexpired redemption periods until March 1, 1935. The extension had to be requested by the mortgagor, and could be denied for "good cause." During the extension, a "just and equitable" portion of the income of the mortgaged property had to be applied toward current taxes and such other purposes as the court might direct. ${ }^{19}$

The mortgage foreclosure continuance and redemption period extension laws were the session's two most dramatic relief measures, but three other enactments altered important aspects of the mortgage foreclosure process. The first modified the operation of receiverships to enforce mortgage pledges of the rents and profits of mortgaged land during the period between the commencement of a foreclosure proceeding and the end of the one-year redemption period. Races among mortgagees to be the first to commence foreclosure proceedings had been triggered by a 1927 Iowa Supreme Court decision that had awarded priority in rents and profits to a junior mortgagee who

stated that they would abide by the proclamation. See Woodruff, Farm Mortgage Loans, 103; and Shover, Cornbelt Rebellion, 86. In an address to the General Assembly two years later, Governor Herring commented that although the proclamation "perhaps ... had no legal basis upon which to rest, ... it did have the earnest, wholehearted approval of the people of Iowa, and so approved, it became as powerful as law itself." 1935 Iowa Senate Journal 22.

18. Ch. 182, 1933 Iowa Acts 211.

19. Ch. 179, 1933 Iowa Acts 208. 
had requested the appointment of a receiver before like action had been taken by the senior mortgagee. ${ }^{20}$ To eliminate this destabilizing incentive, the General Assembly provided that priorities in rents and profits were to be determined by the priority of mortgage liens. In the same enactment, the owner in actual possession of mortgaged land was afforded a preference in leasing it from a receiver, and taxes and insurance were made first claims against the receivership's net proceeds. It was expressly provided, however, that these changes were not to affect any pending litigation. ${ }^{21}$

Another enactment addressed part of the effects of deficiency judgments by temporarily increasing the amount of personal property that was exempt from levy under general execution. Existing law already exempted various types and amounts of personal property. ${ }^{22}$ This measure provided that an additional five hundred dollars of farm and household goods could be claimed as exempt until March 1, 1935. An express provision that this additional exemption could not be applied to existing property as against an existing obligation confined its retrospective effect to subsequently acquired farm and household goods. ${ }^{23}$

The session's final relief measure imposed a relatively more substantial restriction on the enforcement of deficiency judgments. Under existing law, all judgments were effective for at least twenty years, and could be renewed for additional twenty-year periods for the duration of the judgment debtor's life. ${ }^{24}$ An enactment effective as of January 1, 1934, however, provided that deficiency judgments could be enforced for only two years from their date of entry, and were incapable of being renewed. ${ }^{25}$ Thus, after this two-year period had expired, a mortgagor's other property would no longer be subject to any

20. Lynch v. Donahoe, 205 Iowa 537, 215 N.W. 736 (1927).

21. Ch. 181, 1933 Iowa Acts 210 (current version at Iowa Code §̧ 654.13-.14 (1987)).

22. Iowa Code §̧ 11760 (1931).

23. Ch. 177, 1933 Iowa Acts 206.

24. Iowa Code §̧̧ 11007(7), 11649 (1931) (current versions at Iowa Code $\S \S 614.1(6), 626.2(1987))$.

25. Ch. 178, 1933 Iowa Acts 207 (current versions at Iowa Code §̧ 615.1-.2 (1987)). 
portion of the mortgage debt not satisfied by a sale of the mortgaged land.

The subject matter of each of these enactments had been addressed by a large number of other bills which would have effected more substantial changes of existing foreclosure law. ${ }^{26}$

26. The large number and wide variety of unenacted relief measures introduced during the course of the Forty-fifth General Assembly's regular session may be summarized under the following headings: (1) Delay of Mortgage Foreclosure Proceedings: S.F. 113 (mortgagor's obligation to file answer deferred to eighteen months); S.F. 196 (mortgagor's obligation to file answer deferred until 22 January 1935); H.F. 218 (all foreclosure proceedings continued until 1 March 1935 in absence of waste with income apportionment by three-person arbitration committee); H.F. 564 (same). (2) Extension of Redemption Periods: S.F. 182 (extended to three years); H.F. 136 (extended to two years); H.F. 518 (extended to three years). (3) Restrictions on Mortgage Receiverships: S.F. 181 (no receiver if two-fifths of annual crops tendered to mortgagee); S.F. 228 (pledge of rents and profits effective from date of mortgage); S.F. 286 (receivership hearing must be held before sale); H.F. 137 (pledges of rents and profits prohibited); H.F. 185 (lease preference for owner, deficiency judgment not enforceable against crops and livestock); H.F. 391 (occurrence of deficiency at sale cannot be considered in determining adequacy of security in receivership hearings); H.F. 440 (no receiver if twofifths of annual crops tendered to mortgagee). (4) Deficiency Judgment Limitations: S.F. 117 (deficiency judgments abolished); S.F. 186 (same); S.F. 216 (period in which judgments can be enforced by execution reduced from twenty years to ten years); S.F. 219 (deficiency judgments abolished); S.F. 268 (period in which judgment is lien on real property reduced from ten years to five years); S.F. 438 (no personal action on note within state until exhaustion of mortgage security outside of state); H.F. 88 (no deficiency judgment unless mortgagee rebuts presumption that value of land equal to amount of debt, with mortgagor entitled to demand that value be determined by a jury); H.F. 92 (deficiency judgment must be obtained in separate law action in which mortgagee must prove that value of land is less than amount of debt); H.F. 195 (deficiency judgments abolished); H.F. 288 (same); H.F. 316 (same); H.F. 502 (same). (5) Increased Exemptions: S.F. 94 (additional five hundred dollars of personalty for four years); H.F. 111 (same); H.F. 306 (expansion of real property homestead exemption from forty acres to eighty acres). (6) Execution Sale Procedures: S.F. 99 (land redeemed by owner not liable for any deficiency); S.F. 101 (sheriff must follow plan of division submitted by mortgagor). (7) Forfeiture of Land Contracts: H.F. 314 (change of contract forfeiture period from thirty days to between fifteen and 280 days depending on percentage of purchase price paid by vendee). (8) Prohibited Mortgage Provisions: S.F. 118 (single mortgage cannot secure both present and future indebtedness); S.F. 155 (acceleration clauses prohibited); S.F. 251 (mortgage provision encompassing future indebtedness must specify nature and amount of such indebtedness). (9) Taxation of Judgments and Deficiencies: S.F. 183 (no entry of judgment unless mortgagee pays tax equal to "unearned increment" consisting of excess of nominal amount of debt over real value of loan; also 50 percent tax on deficiency judgments, with judgment extinguished if tax not paid 
According to the Des Moines Register's head statehouse correspondent, the General Assembly's rejection of these relatively more radical possibilities was the result of a deliberate effort to craft mortgagor relief measures which the courts might be able to uphold.

Probably there never has been a time since the constitutional conventions when there has been so much argument over the constitutionality of bills as has been heard on capitol hill in the last 102 days. ...

The emergency acts, by common consent, were conceded to have stretched the constitution, if not to have violated it under normal conditions. The acts approved, however, were clothed in the police and emergency powers of the state, and were made self expiring in two years....

It is probable that the acts of emergency nature will be subjected to litigation, ... but what the legislators, who consented to going as far as some of the acts went, followed as a policy was not to run wild on what they sanctioned in the name of emergency.

There were two distinct lines of thought on the emergency legislation. One was to pass measures attorneys knew would not stand court scrutiny and let them go into effect in anticipation that their operation would continue for a long time before the courts reach final decisions holding them invalid. The other, which prevailed, was to stop with such acts as might reasonably be expected to hold water. ${ }^{27}$

The anticipated constitutional challenges soon materialized. ${ }^{28}$ Judicial vindication of the General Assembly's relative

within thirty days); S.F. 184 (50 percent tax on deficiency judgments, with judgment extinguished if tax not paid within thirty days); S.F. 185 (10 percent tax on judgments); S.F. 188 (5 percent tax on judgments); H.F. 477 (5 percent tax on judgments); H.F. 500 (10 percent tax on judgments); H.F. 515 (50 percent tax on deficiency judgments, with judgment extinguished if tax not paid within thirty days).

27. Des Moines Register, 23 April 1933, 1-L.

28. Des Moines Register, 19 March 1933, 1-L, 29 April 1933, 12. A notable aspect of the infamous incident of the assault of Iowa District Court Judge C. C. Bradley in Le Mars is that the assault had been preceded by the judge's refusal to accede to demands that he uphold the constitutionality of the mortgage foreclosure continuance and redemption period extension laws because he had not had sufficient time to study the cases before him in which the con- 
moderation occurred approximately a year later. Meanwhile, however, major parts of the context in which Iowa's mortgagor relief laws would function were determined by the content and operation of the New Deal's agricultural income and credit programs.

THREE WEEKS AFTER THE ADJOURNMENT of the regular session of the Forty-fifth General Assembly, the United States Congress enacted the Agricultural Adjustment Act and the Emergency Farm Mortgage Act. ${ }^{29}$ Before the Agricultural Adjustment Act was declared unconstitutional by the United States Supreme Court in early $1936,{ }^{30}$ it provided a set of programs which significantly enhanced the income of many Iowa farmers. The non-recourse corn loan program instituted in late 1933 generated proceeds of sixty million dollars, and a fortyfive-million-dollar net increase in gross farm income was estimated to have resulted from the payments of ninety million dollars made pursuant to corn and hog production limitation contracts during 1934 and $1935 .{ }^{31}$ Further benefits were forthcoming during the remainder of the decade through the price and income programs implemented under the Soil Conservation and Domestic Allotment Act of 1936 and the Agricultural Adjustment Act of $1938 .^{32}$

stitutionality of such laws was being challenged. Des Moines Register, 28 April 1933, 1, 12.

29. Agricultural Adjustment Act of 1933 , ch. 25, tit. I, 48 Stat. 31, 31; Emergency Farm Mortgage Act of 1933, ch. 25, tit. II, 48 Stat. 31, 41.

30. United States v. Butler, 297 U.S. 1 (1936).

31. Richard H. Roberts, "Economic Effects of the Corn-Hog Program in Iowa," Iowa Journal of History and Politics 34 (April 1936), 144, 153, 165.

32. Soil Conservation and Domestic Allotment Act of 1936, ch. 104, 49 Stat. 1148; Agricultural Adjustment Act of 1938, ch. 30, 52 Stat. 31. The primary dimensions of federal agricultural price and income support programs during the 1930s are summarized in Wayne D. Rasmussen and Gladys L. Baker, Price-Support and Adjustment Programs from 1933 through 1978: A Short History (Washington, DC, 1979), 3-15; and the general scope and orientation of New Deal agricultural policies and programs are described and evaluated in Harold F. Breimyer, "Agricultural Philosophies and Policies in the New Deal," Minnesota Law Review 68 (December 1983), 333, and Wayne D. Rasmussen, "New Deal Agricultural Policies after Fifty Years," Minnesota Law Review 68 (December 1983), 353. For more detailed examinations of federal agricultural 
Assistance aimed more directly to farm mortgagors was provided by two major farm mortgage loan programs established by the Emergency Farm Mortgage Act. In one, financial assistance was provided to the federal land banks to support new loans for the refinancing of existing indebtedness and to subsidize reduced interest rates and various kinds of repayment extensions for both old and new federal land bank loans. In the other, existing indebtedness was refinanced upon favorable rates and terms through "land bank commissioner" loans made directly by a federal entity. ${ }^{33}$

Between 1933 and 1940, the loans made in Iowa under the two programs totalled almost $\$ 250$ million (see table 2). It appears that most of the proceeds of these loans were used to refinance existing debts, and that most refinanced debts were mortgages previously held by individuals, commercial banks, and insurance companies. ${ }^{34}$ While most mortgages continued to be held by private lenders, somewhere between one-quarter and one-third of total outstanding mortgage debt was shifted from such lenders through the federal refinancing effort (compare tables 1 and 2).

The availability and the effects of these refinancing loans were influenced by the loan standards applied by the two federal programs. Federal land bank loans had to be secured by first mortgages, and could be for up to 50 percent of the value of the land and 20 percent of the value of any improvements as determined by an appraisal of the "normal value" of the land and improvements under economic conditions approximating those prevailing before the economic boom of the 1910s. Land bank commissioner loans used the same appraisal standard, but could be secured by second mortgages and could extend

programs during the Great Depression, see Murray R. Benedict, Farm Policies of the United States, 1790-1950: A Study of Their Origins and Development (New York, 1953), 276-401; Theodore Saloutos and John D. Hicks, Agricultural Discontent in the Middle West, 1900-1939 (Madison, 1951), 452-57; and Theodore Saloutos, The American Farmer and the New Deal (Ames, 1982).

33. Donald C. Horton, Harald C. Larsen, and Norman J. Wall, FarmMortgage Credit Facilities in the United States (Washington, DC, 1942), 77-90, 109-16.

34. Robert H. Skilton, Government and the Mortgage Debtor (1929 to 1939) (Philadelphia, 1944), 155. 


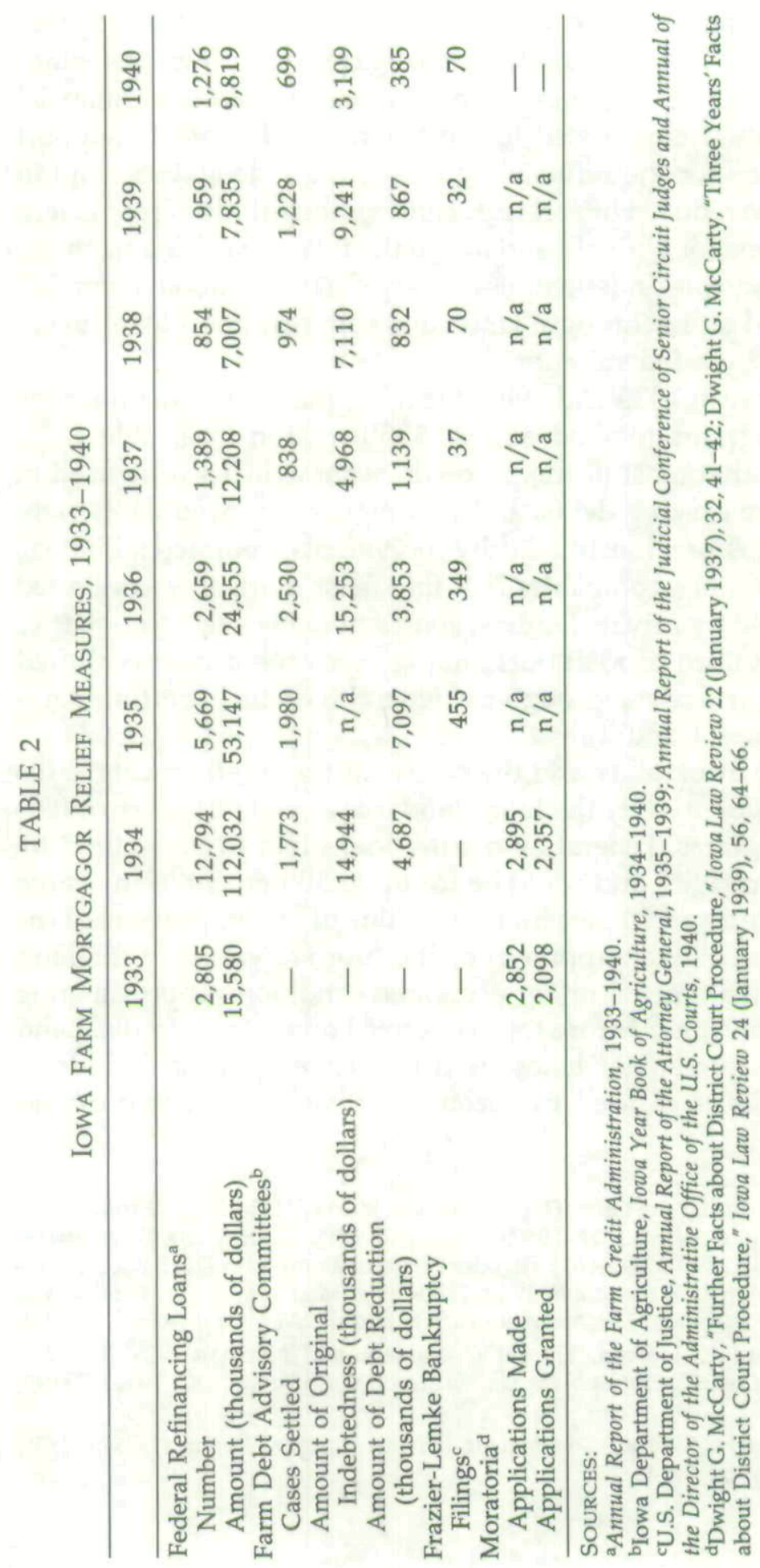


up to 75 percent of the value of the land and any improvements. Under either program, however, a loan generally would not be made if the proceeds would not fully discharge the farmer's existing indebtedness. ${ }^{35}$

To facilitate voluntary write-downs of debts in amounts sufficient to meet this requirement of federal refinancing, the nation's governors were asked to appoint committees of local residents in each county to serve as mediators between farm debtors and their creditors. ${ }^{36}$ Iowa's system of Farm Debt Advisory Committees was operational by early 1934, and continued to function into the early $1940 \mathrm{~s}$. The committees served without pay, and had no authority either to compel participation or to bind participants. Cases involving applications for federal refinancing of existing mortgages initially occupied much of their time, but the committees also considered a broad range of other farm credit matters. During their first three years of operation, the committees handled more than twenty-two thousand cases, and obtained more than six thousand settlements involving aggregate debt reductions of more than fifteen million dollars. By the time annual reports ceased in 1942, the committees had settled more than ten thousand cases in which the average reduction of debt was slightly more than $\$ 1,800 .{ }^{37}$

In mid-1934, the carrot of federal mortgage refinancing programs was complemented by the stick of an amended chapter of the federal Bankruptcy Act which permitted farmers to satisfy mortgage debts by paying to the mortgagee the appraised value of the mortgaged land. The Frazier-Lemke Act provided a useful alternative to farmers who could not obtain

35. Horton, Larsen, and Wall, Farm-Mortgage Credit Facilities, 83, 88-89, 114; Skilton, Government and the Mortgage Debtor, 151; Woodruff, Farm Mortgage Loans, 145.

36. Skilton, Government and the Mortgage Debtor, 151-52; Woodruff, Farm Mortgage Loans, 145-46. For somewhat differing views of the accomplishments of these committees, see H. C. M. Case, "Farm Debt Adjustment During the Early 1930s," Agricultural History 34 (July 1960), 173-81, and Ernest Feder, "Farm Debt Adjustments During the Depression-The Other Side of the Coin," Agricultural History 35 (January 1961), 78-81.

37. Iowa State Department of Agriculture, Iowa Year Book of Agriculture (1934), 226-59; (1935), 196-200; (1936), 226-28, 238-39; (1937), 227-28, 237-43; (1938), 208-9; (1939), 253-54; (1940), 279-81; (1941), 322. 
consensual reductions of mortgage indebtedness. ${ }^{38}$ Within less than a year, however, a unanimous United States Supreme Court ruled that it effected an unconstitutional taking of the property rights of mortgagees. ${ }^{39} \mathrm{~A}$ replacement enacted in August of 1935 involving somewhat more limited adjustments of the enforcement remedies of farm mortgagees was sustained by a unanimous Supreme Court in $1937 .{ }^{40}$ Over the course of the next three years, the provisions of this second FrazierLemke Act were construed to approximate many of the functions of the first Frazier-Lemke Act. ${ }^{41}$ In Iowa, an initial surge of filings under the first Frazier-Lemke Act was followed by a much smaller number of filings under the second FrazierLemke Act, and many of the proceedings were concluded before favorable judicial constructions of the provisions of the second Frazier-Lemke Act were rendered (see table 2). The availability of relief under the Frazier-Lemke Acts, however, commonly was claimed to have prompted a large number of consensual arrangements in which farm mortgages were altered to reduce payment obligations to manageable levels. ${ }^{42}$

MORE THAN HALF OF THE STATES enacted mortgagor relief legislation during $1933 .{ }^{43}$ With notable speed, a case challenging the constitutionality of Minnesota's mortgage moratorium statute came before the United States Supreme Court in January 1934. Home Building \& Loan Association v. Blaisdell

38. Federal Farm Bankruptcy Act, ch. 869, 48 Stat. 1289 (1934).

39. Louisville Joint Stock Land Bank v. Radford, 295 U.S. 555 (1935).

40. Farm Mortgage Moratorium Act, ch. 792, 49 Stat. 942 (1935); Wright v. Vinton Branch of the Mountain Trust Bank of Roanoke, 300 U.S. 440 (1937). 41. Wright v. Union Cent. Life Ins. Co., 304 U.S. 502 (1938); John Hancock Mut. Life Ins. Co. v. Bartels, 308 U.S. 180 (1939); Wright v. Union Cent. Life Ins. Co., 311 U.S. 273 (1940).

42. Farm Mortgage Moratorium: Hearings on S. 2215 and H.R. 6452 Before the Special Subcomm. on Bankruptcy of the House Comm. on the Judiciary, 75th Cong., $2 \mathrm{~d}$ and $3 \mathrm{~d}$ sess. (1937-38), 37, 55-56, 171, 207, 208, 210, 211, 213, 230, 249, 250, 255 (hereafter 1938 Frazier-Lemke Extension Hearings); Case, "Farm Debt Adjustment," 180.

43. Skilton, Government and the Mortgage Debtor, 78-136; Woodruff, Farm Mortgage Loans, 171-82; Lee J. Alston, "Farm Foreclosure Moratorium Legislation: A Lesson from the Past," American Economic Review 74 (June 1984), 445; J. Douglass Poteat, "State Legislative Relief for the Mortgage Debtor During the Depression," Law and Contemporary Problems 5 (Fall 1938), 517. 
involved a law that authorized the postponement of mortgage foreclosure and judgment execution sales and the extension of unexpired statutory redemption periods until the earlier of either the end of the existing economic emergency or May 1, 1935. During the postponement or extension, the law required that a reasonable part of the income or rental value of the property be applied toward taxes, insurance, and mortgage interest and indebtedness. By a vote of 5-4, the Court ruled that the Minnesota statute did not violate the contract clause of the federal constitution. ${ }^{44}$

In his opinion for the majority, Chief Justice Hughes observed that the contract clause was phrased in general terms which necessitated further judicial construction, and that the Court's view of the meaning of those terms had evolved to include a recognition that the clause's limitation of the states' ability to affect the enforcement of private contracts was subject to the "police power" which the states reserved as an inherent aspect of their sovereignty.

The [State's] reserved [police] power cannot be construed so as to destroy the limitation [of the contract clause], nor is the limitation to be construed to destroy the reserved power in its essential aspects. They must be construed in harmony with each other. This principle precludes a construction which would permit the State to adopt as its policy the repudiation of debts or the destruction of contracts or the denial of means to enforce them. But it does not follow that conditions may not arise in which a temporary restraint of enforcement may be consistent with the spirit and purpose of the [limitation] and thus be found to be within the range of the reserved power of the State to protect the vital interests of the community.

Chief Justice Hughes contrasted the temporary and qualified nature of the Minnesota statute with the generally permanent and absolute character of the debtor relief measures at issue in the major nineteenth-century contract clause cases, and con-

44. Home Building \& Loan Association v. Blaisdell, 290 U.S. 398 (1934). A detailed description of the enactment and operation of the moratorium law upheld in Blaisdell is provided in William L. Prosser, "The Minnesota Mortgage Moratorium," Southern California Law Review 7 (May 1934), 353. 
cluded that the Minnesota statute was constitutional because it had been enacted in response to and was limited by the duration of a condition of economic emergency, and because it required the payment of rent by the mortgagor for the period in which further enforcement of the mortgage was delayed. ${ }^{45}$

In a dissenting opinion joined by three others, Justice Sutherland emphasized that the contract clause "was meant to foreclose state action impairing contracts primarily and especially in respect of such action aimed at giving relief to debtors in time of emergency." After arguing that the Court previously had always construed the clause as a barrier to relief measures like the Minnesota statute, he concluded, "If the provisions of the Constitution be not upheld when they pinch as well as when they comfort, they may as well be abandoned." 46

Three months later, Blaisdell served as the mainstay of the Iowa Supreme Court's 5-4 decision in Des Moines Joint Stock Land Bank $v$. Nordholm. ${ }^{47}$ In upholding the redemption period extension law the General Assembly had enacted a year earlier, the majority opinion molded the law to fit the specific contours of Blaisdell in two respects. First, it ruled that the law's provision that a "just and equitable" part of the property's income be applied to the payment of taxes and such other purposes as "the court may direct" required payment to the mortgagee of reasonable compensation for the extension's deferral of the mortgagee's right to obtain title and possession at the end of the redemption period. Second, it provided that the extension was subject to change at the request of the mortgagee if the economic emergency ended before March 1, 1935. The majority's conclusion that the law so construed was consistent with Blaisdell's reckoning of the requirements of the federal contract clause was followed by a determination that Iowa's contract clause was of like dimensions. ${ }^{48}$

45. 290 U.S. $398,426-29,431-34,439,444-47$.

46. Ibid., 465-72, 483.

47. 217 Iowa 1319, 253 N.W. 701 (1934). An interesting connection between the two cases is that Professor Vernon A. Vrooman of the Drake University Law School appeared in both as an amicus curiae. 78 L.Ed. 413, 416; 217 Iowa at 1320,253 N.W. at 702 .

48. 217 Iowa at $1331-33,1342,253$ N.W. at $707-9,713$. 
Three of the four dissenters argued that a requirement of reasonable compensation to the mortgagee could not fairly be found in the law, and that the absence of such a requirement placed the law outside of the limits established by Blaisdell. Moreover, a different grouping of three dissenters contended that the state contract clause was stouter than the federal contract clause, and concluded that the law violated the former even if it did not violate the latter. ${ }^{49}$

Later in the year, the Iowa Supreme Court followed Nordholm in rejecting a constitutional challenge to the 1933 mortgage foreclosure continuance law. ${ }^{50} \mathrm{~A}$ federal district court also relied on Blaisdell in sustaining the 1933 exemption increase law. ${ }^{51}$ In early 1936 the Iowa Supreme Court upheld the 1933 law imposing a two-year restriction on the enforcement of deficiency judgments on the somewhat more traditionally recognized ground that contracts are not impaired by a shortening of a limitations period that leaves a reasonable period within which contracts affected by the shortening can be enforced. ${ }^{52}$ Because it expressly did not affect pending litigation, the remaining 1933 enactment establishing the order of priority between the holders of pledges of rents and profits never was the subject of a constitutional determination. ${ }^{53}$

WHEN THE FORTY-SIXTH GENERAL ASSEMBLY convened in January 1935, Governor Herring recommended the prompt enactment of legislation extending the temporary mortgagor relief measures which had been in place since $1933 .{ }^{54}$

49. 217 Iowa at $1347-89,253$ N.W. at 715-36.

50. Craig v. Waggoner, 218 Iowa 876, 256 N.W. 285 (1934).

51. In re Durband, 8 F. Supp. 63 (N.D. Iowa 1934).

52. Berg v. Berg, 221 Iowa 326, 264 N.W. 821 (1936).

53. After initially suggesting that the law could not constitutionally be applied to pending cases (First Trust Joint Stock Land Bank v. Smith, 219 Iowa $658,660-61,259$ N.W. 192, 193 [1935]), the court ruled that such result followed from the law's own exclusion of pending cases from the ambit of its effects (First Joint Stock Land Bank v. Armstrong, 220 Iowa 416, 418-21, 262 N.W. 815, 816-17 [1935]).

54. Toward the conclusion of its extra session in mid-March 1934, the Fortyfifth General Assembly had modified the scope of the mortgage foreclosure continuance and redemption period extension laws enacted a year earlier in 
Two years ago the Forty-fifth General Assembly passed moratorium laws for the protection of distressed farm and home owners. Under the operation of these laws thousands of evictions have been averted and millions of dollars in federal refinancing of Iowa farms and homes has been made possible. Debtors who dealt fairly with their creditors have been protected, and at the same time creditors have been protected against unfair debtors. Courts have sustained the validity of this legislation. As we emerge from the depression, and values of Iowa real estate increase, the pressure upon the debtor is intensified. Thousands of debtors in Iowa need a continuance of this protection, and I urge that the present moratorium laws be extended for two years from their present expiration date-March 1, 1935. ${ }^{55}$

By the end of the first week in February, all three existing temporary mortgagor relief laws had been reenacted in revised forms which were effective until March 1, 1937.

The 1935 mortgage foreclosure continuance law substantially paralleled its 1933 predecessor in authorizing the courts to grant continuances of pending or subsequently commenced foreclosure proceedings upon application by the mortgagor and in the absence of good cause to the contrary, with possession of the mortgaged land being retained by the mortgagor upon payment of a fair rent. The transition between the two laws was accomplished through a provision by which all applications previously granted or currently pending under the 1933 law were deemed to be refiled under the 1935 law. A previously enacted exclusion of mortgages executed after January 1, 1934, was expanded to include any assumption of a mortgage after that date unless a continuance concerning the mortgage previously had been granted, and another provision specified that

its regular session by providing that neither law would be applicable to real estate mortgages executed after 1 January 1934 . Ch. 137, 1933-1934 Iowa Acts 260 . This restriction of the laws' prospective effects apparently was intended to facilitate the refinancing of mortgages under federal farm and home mortgage loan programs, and also to encourage new extensions of mortgage credit by private lenders. These new mortgage loans normally might be in amounts which mortgagors could meet under prevailing economic conditions, and correspondingly, most of the mortgage loans which might be the subject of pending or subsequently commenced foreclosure proceedings probably had been incurred prior to 1934 .

55. 1935 Iowa Senate Journal 52-53. 
the 1935 law was applicable to any pre-1934 mortgage which had been renewed since January $1,1934 . .^{56}$

The 1935 redemption period extension law also substantially paralleled its 1933 predecessor in authorizing the courts to grant extensions of unexpired redemption periods upon application by the mortgagor and in the absence of good cause to the contrary, with a fair and equitable portion of the income of the mortgaged land being applied toward the payment of taxes and such other purposes as the court might direct. Extensions were available only in proceedings commenced before March 1, 1935, and additional eligibility criteria for recently executed, assumed, and renewed mortgages were the same as for mortgage foreclosure continuances, except that the applicable cut-off point was moved forward to March 1, 1934. In contrast to the essentially self-executing transition between the 1933 and 1935 mortgage foreclosure continuance laws, extensions previously granted under the 1933 redemption period extension law would expire on March 1, 1935 if a mortgagor did not file an application under the 1935 law before then. ${ }^{57}$

The 1935 increased exemption law likewise substantially paralleled its 1933 predecessor in temporarily establishing an additional five-hundred-dollar exemption for farm and household goods. Although an exclusion concerning property and obligations in existence on the date of the enactment of the 1933 law was carried forward into the 1935 law, an exception to the exclusion was created for up to one hundred dollars of household goods, and another provision seemingly made that same amount of household goods exempt even as against a chattel mortgage..$^{58}$

In addition to renewing these three temporary mortgagor relief measures, the General Assembly enacted a fourth temporary measure which enabled buyers under land contracts to obtain relief comparable to that which mortgagors could obtain under the mortgage foreclosure continuance law. Although a land contract cannot be used by a lender, it can be used by a seller to perform an economic function identical to that per-

56. Ch. 115, 1935 Iowa Acts 162.

57. Ch. 110, 1935 Iowa Acts 155.

58. Ch. 109, 1935 Iowa Acts 154. 
formed by a mortgage. Perhaps because most sellers normally are individuals, however, land contract enforcement procedures generally have afforded buyers considerably less protection than mortgage foreclosure procedures have afforded to mortgagors. ${ }^{59}$ Nevertheless, during the first week of the session both the Iowa Farm Debt Advisory Council and the Iowa Farm Bureau had recommended that land contract buyers be protected by legislation paralleling that available to mortgagors. ${ }^{60}$ Under the enacted law, courts were authorized to continue land contract foreclosures and to abate land contract forfeitures upon timely application by the buyer, and could allow the buyer to remain in possession of the land during the continuance or abatement upon payment of a fair rent. A continuance or abatement could be denied for "good cause," and in making such determination, the courts were to consider the amount of the buyer's down payment and the extent of payments made upon the contract. ${ }^{61}$

A final mortgagor relief measure apparently was intended to close a loophole in the 1933 law that permanently had imposed a two-year limitation on the enforcement of deficiency judgments. Since it applied only to judgments in proceedings to foreclose a mortgage, a mortgagee could avoid the effects of the 1933 law by waiving the security of the mortgage and suing only on the underlying debt. In the 1935 enactment, however, the two-year limitation was enlarged to include judgments entered on mortgage debts where the mortgage itself had not been enforced. ${ }^{62}$

59. Marshall Harris and N. William Hines, Installment Land Contracts in Iowa (Iowa City, 1965), 9-10, 79-100; Douglas Rendleman, "Absolute Conveyance as a Mortgage in Iowa," Drake Law Review 18 (May 1969), 197, 205-8; Charles F. Becker, "Remedying the Inequities of Forfeiture in Land Installment Contracts," Iowa Law Review 64 (October 1978), 158; "Forfeiture and the Iowa Installment Land Contract," Iowa Law Review 46 (Winter 1961), 786.

60. Des Moines Register, 19 January 1935, 4.

61. Ch. 117, 1935 Iowa Acts 165.

62. Ch. 108, 1935 Iowa Acts 153 (current version, as amended, at Iowa Code $\S 615.3$ (1987)). The nature of the loophole in the 1933 law is described in Gordon B. Wheeler and Edgar N. Durfee, "Evasion of Mortgage Moratoria by Prosecution of Personal Remedies," Michigan Law Review 33 (June 1935), 1196; and the combined effects of the 1933 and 1935 laws are analyzed in 
When the Forty-seventh General Assembly convened in January 1937, newly elected Governor Nelson G. Kraschel cited the adverse crop conditions of the previous year as a major reason for a further extension of temporary mortgagor relief measures.

The financial distress in the drouth counties of the state has created a situation that requires, in the public interest, that the farm debt moratorium law be extended. The ownership of approximately thirteen thousand ... farms is being protected for their owners by the present moratorium law which expires March 1, 1937. If the law should not be extended, thousands of practical and dependable farmers would lose their farm homes. Such a wholesale loss of ownership would be a major disaster, not alone to the farmers who lose title to land, but to the communities in which they live, because of the tremendous increase in the number of farms that will be added to the already menacing problem of farm tenancy.63

In a proclamation issued approximately a month later, Governor Kraschel declared that further relief was warranted both by the existence of the new emergency resulting from the natural calamities of 1936 and by the persistence of the original economic emergency that had occasioned the relief measures previously enacted in 1933 and $1935 .{ }^{64}$

The governor's proclamation and the existence of both emergencies were cited by the General Assembly as reasons for its revision and extension until March 1, 1939, of three of the four temporary measures enacted in 1935 . The 1935 land contract foreclosure continuance and forfeiture abatement law, however, expired on March 1, 1937 after a renewal bill passed by the House was indefinitely postponed by the Senate. ${ }^{65}$ The 1937 mortgage foreclosure continuance and redemption period extension laws differed from their 1935 counterparts in only

"Limitations on Post Judgment Proceedings by the Plaintiff," Iowa Law Review 42 (Winter 1957), 299.

63. 1937 Iowa Senate Journal 65.

64. Ibid., 270-71.

65. H.F. 219, 47th Iowa Gen. Assem. (1937); 1937 Iowa House Journal 433-

34; 1937 Iowa Senate Journal 405-6. 
two material respects. First, the eligibility cut-off dates for newly executed mortgages were moved from January 1, 1934, and March 1, 1934, respectively, to January 1, 1936. Second, both laws attempted to reverse judicially developed restrictions on the availability of relief by specifying that insolvency of the mortgagor and inadequacy of the security were not sufficient "good cause" for denying a continuance or an extension. The only material difference between the 1937 and 1935 exemption increase laws was that the former prohibited additional exemption claims based on a decrease in the value of previously exempted property. ${ }^{66}$

THE IOWA SUPREME COURT ultimately issued more than ninety published opinions resolving various issues posed by the existence or operation of the mortgage foreclosure continuance and redemption period extension laws. ${ }^{67}$ Many outer dimensions of the laws were affected by opinions involving such issues as the types of persons eligible to apply for continuances or extensions, ${ }^{68}$ the time when applications had to be made, ${ }^{69}$ or the rent to be paid to the mortgagee during a continuance or an extension. ${ }^{70}$ Within those outer dimensions, however, the administration of the laws was influenced to a considerable

66. Ch. 78, 80, 82, 1937 Iowa Acts 92, 95, 99.

67. 50 Iowa Code Ann. (West 1950), 335-54.

68. See, for example, Equitable Life Assurance Soc'y v. Kramer, 218 Iowa 80, 253 N.W. 809 (1934) (extension not available to a junior lienholder), and Prudential Ins. Co. v. Kraschel, 222 Iowa 128, 266 N.W. 550 (1936) (all owners must join in request for continuance).

69. See, for example, Mohns v. Kasperbauer, 220 Iowa 1168, 263 N.W. 833 (1935) (extension cannot be granted after expiration of redemption period); Lincoln Joint Stock Land Bank v. Hansen, 221 Iowa 21, 263 N.W. 821 (1935) (continuance cannot be granted after entry of foreclosure decree); Connecticut Mut. Life Ins. Co. v. Crozier, 221 Iowa 38, 265 N.W. 166 (1936) (1933 redemption period extension law not applicable to proceedings commenced after its enactment); and Prudential Ins. Co. v. Kelley, 225 Iowa 175, 279 N.W. 416 (1938) (under 1937 redemption period extension law, extension previously granted extended by request made before expiration of previous extension).

70. See, for example, McDonald v. Ferring, 218 Iowa 593, 255 N.W. 719 (1934) (continuance cannot be granted without provision for payment of rent), and John Hancock Mut. Life Ins. Co. v. McFee, 222 Iowa 403, 269 N.W. 332 (1936) (continuance can be revoked if ordered rent not paid). 
degree by opinions determining the burden of proof, the standard of review, and the meaning of the phrase "good cause." Although elaborations were developed in more than forty ensuing opinions, the basic nature of each of these three issues was established in one of the court's first opinions.

The granting of the continuance is to be the rule under the statute, and, if the general rule is not to apply, the mortgagee must show good cause as to why it should not govern.... As to what may be a good cause in such event is not provided in the statute. So the statute, in effect, contemplates that the district court, in harmony with the purposes and provisions of the act, shall determine what shall be such good cause, and, if that court does not abuse its limited discretion in that event, this court will not interfere. $^{71}$

Since a mortgagor who discharged the burden of initiation by filing an application presumptively was entitled to a continuance or extension, district courts could deny relief only if the mortgagee satisfied its burden of establishing that relief would be contrary to the purposes of the legislation. ${ }^{72}$ Moreover, since the district court's determination of this issue would be reviewed by the state supreme court with great deference, in most cases that determination probably would be conclusive. ${ }^{73}$ Nevertheless, significant restrictions on the availability of relief

71. Federal Land Bank v. Wilmarth, 218 Iowa 339, 353, 252 N.W. 507, 513-14 (1934).

72. Connecticut Gen. Life Ins. Co. v. Roth, 218 Iowa 251, 253, 254, 254 N.W. 918, 919 (1934).

73. Prudential Ins. Co. v. Schaefer, 224 Iowa 1243, 1246, 278 N.W. 602,603 (1938) ("[E]ach case must be determined upon its own peculiar facts and the limited discretion of the trial court will not be interfered with on appeal unless such discretion is clearly abused."). The action of the district court in granting or denying a continuance or an extension was affirmed in threefourths of the fifty-two cases in which the primary issue was the correctness of the district court's determination of good cause.

\begin{tabular}{lcc}
\hline & Continuances & Extensions \\
\hline Grant Affirmed & 14 & 12 \\
Denial Affirmed & 10 & 3 \\
Grant Reversed & 7 & 3 \\
Denial Reversed & 3 & 0
\end{tabular}


were established by the supreme court's isolation of some of the primary characteristics of "good cause."

Presumably, only a few persons were much affected or concerned by a series of opinions in which the court ruled that continuances or extensions should not be granted to those fully capable of performing their mortgage obligations, ${ }^{74}$ to those seeking to use the laws to further speculative schemes, ${ }^{75}$ or to those attempting to extort unfair reductions of their mortgage debts. ${ }^{76}$ Greater consequence and controversy, however, clearly followed from a series of opinions in which the court ruled that continuances and extensions were intended only to "afford the owner of the land an opportunity to refinance or pay up the indebtedness ... within the moratorium period." 77 Thus, relief could not properly be granted if the mortgagor was insolvent and the mortgage debt exceeded the value of the mortgaged land, or if it otherwise was clear that the mortgagor had no realistic hope of ever repaying or refinancing the mortgage debt. ${ }^{78}$

The supreme court's initial determination that relief should not be granted in "hopeless" cases was opposed by two dissenting justices who argued that the legislature had not intended such circumstances to be encompassed within "good cause." 79 Nevertheless, between early 1934 and mid-1937, "good cause" provided the basis for denials of relief in a series of opinions involving mortgagors of varying degrees of appar-

74. Butenschoen v. Frye, 219 Iowa 570, 258 N.W. 769 (1935); Fossler v. Breniman, 222 Iowa 124, 268 N.W. 521 (1936); Prudential Ins. Co. v. Kraschel, 222 Iowa 128, 266 N.W. 550 (1936); Equitable Life Assurance Soc'y v. Christensen, 225 Iowa 1258, 282 N.W. 721 (1939).

75. First Trust Joint Stock Land Bank v. Wylie, 221 Iowa 27, 265 N.W. 181 (1936); Equitable Life Assurance Soc'y v. Kirby, 221 Iowa 1150, 266 N.W. 520 (1936); Federal Farm Mortgage Corp. v. Murdock, 225 Iowa 1306, 283 N.W. 95 (1938).

76. Decorah State Bank v. Sexton, 220 Iowa 1047, 264 N.W. 41 (1935); Miller v. Ellison, 221 Iowa 1174, 265 N.W. 908 (1936).

77. Federal Land Bank v. Wilmarth, 218 Iowa 339, 354, 252 N.W. 507, 514 (1934).

78. Reed v. Snow, 218 Iowa 1165, 254 N.W. 800 (1934); First Trust Joint Stock Land Bank v. Runde, 221 Iowa 995, 267 N.W. 691 (1936); John Hancock Mut. Life Ins. Co. v. Schlosser, 222 Iowa 447, 269 N.W. 435 (1936); Mudra v. Brown, 222 Iowa 709, 269 N.W. 753 (1936).

79. Federal Land Bank $v$. Wilmarth, 218 Iowa 339, 355-58, 252 N.W. 507, 514-16 (1934). 
ent worthiness. After the Forty-seventh General Assembly specified that relief should not be denied based solely on insolvency of the mortgagor or inadequacy of the security, however, the court gradually moved toward restricting denials of relief to cases involving the presence of such additional factors as mismanagement or waste. ${ }^{80}$

Iowa's Forty-eighth General Assembly convened on January 9, 1939. The following day the Iowa Supreme Court issued its unanimous decision in First Trust Joint Stock Land Bank v. Arp. ${ }^{81}$ In holding that the 1937 mortgage foreclosure continuance law violated the contract clauses of both the federal and state constitutions, the court reasoned that the validity of relief measures had been eroded both by the passage of time and by the improvement of economic conditions.

Emergency in order to justify the intervention of the reserve police power must be temporary or it cannot be said to be an emergency. If a so-called emergency exists beyond a temporary period then it is no longer an emergency but a status and can furnish no basis or authority for legislative action in contravention of or inconsistent with the provisions of the State and Federal constitutions....

It must be conceded, as we held in the Nordholm case, . . . that an emergency existed in 1933, sufficient to sustain the act of the legislature in enacting the so-called Moratorium Act, but it cannot be said that by reason of such conditions moratorium acts could be re-enacted covering a period of six years, as has been the case in this state.... [P]ractically all of the depressed condi-

80. Compare, for example, First Trust Joint Stock Land Bank v. Abkes, 224 Iowa 877,278 N.W. 183 (1938) (denial of extension affirmed where farming operation consistently unprofitable and waste had occurred) with Metropolitan Life Ins. Co. v. Henderson, 224 Iowa 1238, 278 N.W. 621 (1938) (grant of continuance affirmed despite mortgagor's insolvency and insufficiency of the mortgaged land because crop prices and land values might rise).

81. 225 Iowa 1331, 283 N.W. 441 (1939). The possibility that the pointed timing of the court's decision was not entirely unintentional is suggested by its issuance more than nine months after the case had been fully submitted and argued to the court. "Comment," Iowa Law Review 23 (May 1938), 652, 653. Another sidelight suggestive of some awareness of the political significance of the court's decision is its designation as a per curiam opinion and the presence of a postscript notation that it had been written by a Democratic justice who had been defeated in the 1938 election. 225 Iowa at 1332, 1336, 283 N.W. at 441 . 
tions existing in 1933 ... do not exist at this time. ... Farm values have bettered; the price of farm produce has increased; the banking situation has been made stable and secure ...; [ [and] thousands of Iowa farm homes that were under foreclosure proceedings have been refinanced through the government and other agencies. ${ }^{82}$

To some extent, this assessment of the times was buttressed by the apparent absence of any immediate public or legislative response to the court's decision. Three months later, however, the General Assembly enacted a permanent law authorizing a continuance of a mortgage foreclosure proceeding for up to three years if the default of the mortgagor had been caused by "drought, flood, heat, hail, storm or other climactic conditions or by reason of the infestation of pests," or if "the governor ... by reason of a depression shall have by proclamation declared a state of emergency to exist within this state." 83

There are no reports of any use of this statute in the interim between its enactment and the advent of the agricultural prosperity that accompanied the outbreak of the Second World War. A rather rapid rise in farm product prices was followed at a distance by mounting farmland values, and farm mortgage foreclosures soon became uncommon. ${ }^{84}$ The statute remained on the books, however, and when farm mortgage difficulties recurred four decades later, its revision and activation were among the first steps taken to afford relief to farm mortgagors.

Publications of the state legislature and decisions of the supreme court provide a rather full record of the legislative enactment and judicial construction of Iowa's mortgage foreclosure continuance and redemption period extension laws. The data that would permit a comprehensive assessment of the actual operation of such laws, however, are dispersed among

82. 225 Iowa at $1334-35,283$ N.W. at 443 . In a decision issued one week later, the 1937 redemption period extension law was held unconstitutional on the authority of the court's opinion in Arp. Metropolitan Life Ins. Co. v. McDonald, 225 Iowa 1075, 283 N.W. 445 (1939).

83. Ch. 245, 1939 Iowa Acts 353 (current version, as amended, at Iowa Code § 654.15 (1987)).

84. Bauer, "Judicial Foreclosure and Statutory Redemption," 86. 
thousands of court files in courthouses across the state. Aside from an occasional informal account such as Governor Kraschel's statement that thirteen thousand farms were the subject of continuances or extensions as of early 1937, the only significant published reports are two surveys of district court clerks encompassing cases filed in the two-year period between June 1, 1933, and June 1, 1935. ${ }^{85}$ The surveys include countylevel data indicating the number of foreclosures commenced, the number of "moratorium applications" filed, and the number of applications granted or refused within two years after the end of the annual period in which the foreclosure was initiated. Although the surveys do not distinguish between foreclosures of farm and nonfarm mortgages and may also not fully reflect the possible incidence of redemption period extensions, a few simple analyses of the data offer some interesting perspectives on the probable operation of Iowa's two major mortgagor relief measures (see table 3 ). ${ }^{86}$

Moratorium applications were filed in about 40 percent of the slightly more than fourteen thousand foreclosures commenced in the two years between June 1, 1933, and June 1, 1935. The granting of more than 75 percent of those applications resulted in moratoriums in just under one-third of all foreclosures. Across counties, the percentage of applications filed ranged from just under 15 percent to slightly more than 90 percent, and the percentage of applications granted ranged from

85. 1937 Iowa Senate Journal 65; Dwight G. McCarty, "Further Facts about District Court Procedure," Iowa Law Review 22 (January 1937), 32; Dwight G. McCarty, "Three Years' Facts about District Court Procedure," Iowa Law Review 24 (January 1939), 56.

86. In instances involving a material delay between the commencement of the foreclosure action and the occurrence of the foreclosure sale, a request for a redemption period extension might have been made or acted upon more than two years after the end of the annual period in which the foreclosure had been initiated. Also, it is important to note that the availability of formal relief under the mortgage foreclosure continuance and redemption period extension laws may have prompted informal consensual arrangements upon essentially comparable terms. See Woollums $v$. Anderson, 224 Iowa 264, 275 N.W. 472 (1937) (two-year contractual postponement of due date of mortgage note patterned after terms of 1933 mortgage foreclosure continuance law), and Kleinsorge v. Clark, 232 Iowa 313, 4 N.W.2d 433 (1942) (two-year contractual extension of redemption period patterned after terms of 1933 redemption period extension law). 


\section{TABLE 3}

MORATORIUM Applications IN IOWA MORTGage

Foreclosure CASES, June 1, 1933-MAY 31, 1935a

\begin{tabular}{|c|c|c|c|c|c|}
\hline & \multirow{2}{*}{$\begin{array}{l}\text { Foreclosure } \\
\text { Cases } \\
\text { Commenced }\end{array}$} & \multicolumn{2}{|c|}{$\begin{array}{c}\text { Applications } \\
\text { Filed }\end{array}$} & \multicolumn{2}{|c|}{$\begin{array}{c}\text { Applications } \\
\text { Granted }\end{array}$} \\
\hline & & $\mathrm{N}$ & $\%$ & $\mathrm{~N}$ & $\%$ \\
\hline TOTAL & 14,193 & 5,747 & 40.5 & 4,455 & 77.5 \\
\hline \multicolumn{6}{|l|}{ By Population of County ${ }^{b}$} \\
\hline Under 20,000 & 6,081 & 2,542 & 41.8 & 1,982 & 78.0 \\
\hline $20,000-40,000$ & 3,986 & 1,711 & 42.9 & 1,407 & 82.2 \\
\hline Above 40,000 & 4,126 & 1,494 & 36.2 & 1,066 & 71.4 \\
\hline \multicolumn{6}{|l|}{ By Agricultural Regionc } \\
\hline Western Livestock & 3,230 & 1,682 & 52.1 & 1,372 & 81.6 \\
\hline North-Central Grain & 3,339 & 1,155 & 34.6 & 984 & 85.2 \\
\hline Southern Pasture & 2,269 & 755 & 33.3 & 537 & 71.1 \\
\hline Northeast Dairy & 2,555 & 1,029 & 40.3 & 709 & 68.9 \\
\hline Eastern Livestock & 2,800 & 1,126 & 40.2 & 853 & 75.8 \\
\hline \multicolumn{6}{|l|}{ By Year } \\
\hline June 1, 1933-May 31, 1934 & 7,868 & 2,852 & 36.2 & 2,098 & 73.6 \\
\hline June 1, 1934-May 31, 1935 & 6,325 & 2,895 & 45.8 & 2,357 & 81.4 \\
\hline
\end{tabular}

SOURCES:

aDwight G. McCarty, "Further Facts about District Court Procedure," Iowa Law Review (January 1937), 32, 41-42; Dwight G. McCarty, "Three Years' Facts about District Court Iowa Law Review 24 (January 1939), 56, 64-66.

bIowa Official Register (1931-32), 500-501.

cMarshall Harris and N. William Hines, Installment Land Contracts in Iowa (Iowa City, 1965), 6.

37 percent to 100 percent. Rates at which moratoria were applied for and granted were lower in counties having populations of more than forty thousand, and also varied across the state's five agricultural production regions. Both rates increased during the second of the two years covered by the surveys. ${ }^{87}$

AN EVALUATION of the effectiveness of the mortgagor relief laws that Iowa enacted during the Great Depression must begin with the recognition that their immediate function generally did not extend beyond temporary suspensions of the normal processes for the enforcement of mortgage debts. During such

87. The lower application and granting rates in the first year may reflect the retarding effect of initial constitutional and constructional uncertainties, and the higher application and granting rates in counties having populations under forty thousand suggest that relief most commonly was sought and received by farm mortgagors. 
suspension, the amount of the mortgage debt continued to increase through the accrual of interest, and thus without some material change in the conditions that initially precipitated the foreclosure, the end of the suspension might result in a reckoning less favorable to the mortgagor than that which would have occurred in the absence of a delay. ${ }^{88}$

Between 1933 and 1939, however, a number of material conditions did change. Some farmers regained their capacity to repay their existing mortgage debts with the increase in farm income that followed the waning of the extreme general deflation of the early 1930s and the advent of expansive federal agricultural price and income support programs. Other farmers obtained more favorable terms and conditions of repayment by refinancing their existing mortgage debts through federal land bank and land bank commissioner loans. Some of these farmers also obtained voluntary reductions of the principal amount of their mortgage debts, and still other farmers achieved similar reductions without the consent of their creditors through federal bankruptcy proceedings.

State and federal mortgagor relief measures often worked in conjunction rather than in competition with each other. Thus, the delay afforded by state mortgagor relief laws might have been insufficient in the absence of federal farm income and price support or mortgage refinancing programs, and the impact of these federal programs likewise might have been substantially lessened if large numbers of farmers had lost their land through the normal progress of foreclosure proceedings before the federal programs had been established and fully implemented. ${ }^{89}$ Somewhat differently, the availability to a

88. This aspect of Iowa's mortgagor relief laws was recognized by the Des Moines Register's farm editor shortly after the enactment of the 1933 mortgage foreclosure continuance law in a column entitled "New State Debtors' Emergency Relief Act Offers Only 'Breathing Spell'": "The debtors emergency relief act .... affords delinquent debtors only temporary relief.... Without some improvement either through natural business recovery or congressional action, Mar. 1, 1935, will see the borrower who takes advantage of the new law no better off than he is today. .... Either the farmer's ability to pay must be increased ... or debts must be scaled down." Des Moines Register, 12 February 1933, 2-L.

89. For example, it was observed that "[t]he existing moratorium statutes have ... allowed [Iowa's Farm Debt Advisory Committees] the necessary 
mortgagor of one relief measure might have postponed or eliminated the need for recourse to another, or conversely, a mortgagor might qualify for relief under one measure but not the other. $^{90}$

While the combined workings of state and federal mortgagor relief measures obviously did not save every financially distressed farm mortgagor, they enabled some to hold on until the economic turnabout that began with the onset of the Second World War. Somewhat ironically, this forthcoming phase of relative prosperity would itself set the stage for a dramatic exodus of population from the nation's farms. ${ }^{91}$

In light of the dramatic financial problems facing Iowa's farm mortgagors during the Great Depression, the enactment of mortgagor relief legislation hardly seems surprising. Agriculture's financial problems had been building since the early 1920 s, however, and it is interesting that mortgagor relief measures were not enacted until 1933. Also noteworthy is the rather moderate nature of the enacted mortgagor relief measures relative to more radical relief proposals.

The various means of increasing net farm income that had been pursued during the 1920 s generally had presupposed that agriculture's financial difficulties were temporary and would be corrected within the context of a continuation of the pros-

additional time to work out individual case settlements" (Iowa State Department of Agriculture, Iowa Year Book of Agriculture [1936], 228), and the expiration of state moratoria was cited as a reason both for the enactment of the second Frazier-Lemke Act in 1935 and for extensions of it in 1938 and 1940 (S. Rep. No. 985, 74th Cong., 1st sess., 1935, 7; 1938 Frazier-Lemke Extension Hearings, 178, 257; Farm Mortgage Moratorium: Hearings on H.R. 7528 and S. 1935 Before the Special Subcomm. on Bankruptcy and Reorganization of the House Comm. on the Judiciary, 76th Cong., 3d sess., 1940, 27).

90 . The availability of relief under state mortgagor relief laws was advanced as a major cause of the relatively modest levels of filings under the federal Frazier-Lemke Acts (1938 Frazier-Lemke Extension Hearings, 9-10, 55-56, 232-33). Many farmers were unable to meet the loan standards of the federal refinancing programs (Shover, Cornbelt Rebellion, 142; William G. Murray, Farm Mortgage Policy, [Ames, 1934], 134-35), and that circumstance was cited as a major factor warranting the enactment of the Frazier-Lemke Acts (78 Congressional Record 12,133, 12,135, 12,359 [1934]; 79 Congressional Record 13,639 [1935]).

91. John L. Shover, First Majority - Last Minority: The Transforming of Rural Life in America (DeKalb, IL, 1976), 143-263. 
perity gracing the rest of society. ${ }^{92}$ Furthermore, most farmers involved in foreclosures during the 1920 s had incurred relatively large debts in the boom of the late 1910s, and those borrowing smaller amounts at other times generally had been able to endure the lower farm product prices and farmland values that prevailed before the 1930s. With the end of prosperity in the rest of society and an attendant substantial worsening of the farm economy, mortgage foreclosures became a reality for even modestly indebted farmers, and the prospects for any dramatic reversal of agriculture's financial difficulties grew more remote.

Despite the fact that these events triggered a political changeover of state government, there is little evidence of overt partisanship either in the consideration of such measures by the legislature or in the subsequent construction and application of such measures by the courts. There were few or no opposing votes cast upon final passage of the major mortgagor relief measures enacted between 1933 and 1937 (see table 4). The vast majority of the cases in which the Iowa Supreme Court construed or applied the mortgage foreclosure continuance and redemption period extension laws were also decided without any dissenting opinions. ${ }^{93}$

92. Benedict, Farm Policies, 173-238; Saloutos and Hicks, Agricultural Discontent, 286-403.

93. While three early decisions upholding the constitutionality of the 1933 continuance and extension laws were determined by votes of 5 to 4 , the majority comprised three Democrats and two Republicans, and the dissenters consisted of three Republicans and one Democrat. Des Moines Joint Stock Land Bank v. Nordholm, 217 Iowa 1319, 253 N.W. 701 (1934); Connecticut Gen. Life Ins. Co. v. Roth, 218 Iowa 251, 254 N.W. 918 (1934); Craig v. Waggoner, 218 Iowa 876, 256 N.W. 285 (1934). Five years later, the unanimous decisions invalidating the 1937 continuance and extension laws issued from a bench that contained five Democrats and four Republicans. First Trust Joint Stock Land Bank v. Arp, 225 Iowa 1331, 283 N.W. 441 (1939); Metropolitan Life Ins. Co. v. McDonald, 225 Iowa 1075, 283 N.W. 445 (1939). Apart from the three early decisions upholding the constitutionality of the 1933 continuance and extension laws, the only recorded dissents were in two cases involving the "good cause" exception (Federal Land Bank v. Wilmarth, 218 Iowa 339, 252 N.W. 507 [1934]; Reed v. Snow, 218 Iowa 1165, 254 N.W. 800 [1934]), two cases involving the types of persons eligible to apply for a continuance or an extension (Metropolitan Life Ins. Co. v. Van Alstine, 221 Iowa 763, 226 N.W. 514 [1936]; Prudential Life Ins. Co. v. Kraschel, 222 Iowa 128, 266 N.W. 550 
TABLE 4

General Assembly Votes on Major Mortgagor RELIEF LEGISLATION, 1933-1937

\begin{tabular}{lcc}
\hline & Senate Vote & House Vote \\
\hline 1933 & & \\
Foreclosure Continuances (H.F. 193) & $48-0$ & $104-2$ \\
Redemption Extensions (H.F. 350) & $38-1$ & $103-0$ \\
Receivership Priority (S.F. 115) & $45-2$ & $102-1$ \\
Exemption Increase (S.F. 167) & $36-8$ & $56-43$ \\
$\quad$ Deficiency Limitation (S.F. 267) & $44-1$ & $94-0$ \\
1935 & & \\
Foreclosure Continuances (S.F. 34) & $50-0$ & $104-0$ \\
Redemption Extensions (H.F. 84) & $50-0$ & $105-0$ \\
Exemption Increase (S.F. 57) & $44-0$ & $103-0$ \\
Forfeiture Continuances (S.F. 59) & $47-0$ & $102-2$ \\
$\quad$ Deficiency Limitation (S.F. 176) & $32-4$ & $66-11$ \\
1937 & & \\
Foreclosure Continuances (S.F. 15) & $46-2$ & $99-2$ \\
Redemption Extensions (S.F. 16) & $41-3$ & $99-3$ \\
Exemption Increase (H.F. 233) & $29-14$ & $75-16$ \\
\hline
\end{tabular}

SOURCES: Iowa Senate Journal (1933-1937) and Iowa House Journal (1933-1937).

The apparent existence of broad political support for enacted mortgagor relief measures did not extend to a number of more extreme proposals for the relief of mortgagors or other debtors that did not become law; most never progressed beyond their introduction and reference to a committee. From 1933 through 1937, however, the House passed four bills abolishing or restricting the size of deficiency judgments and three bills extending additional rights to land contract vendees. The House also sought to broaden the reach and scope of enacted mortgagor relief measures in a series of bills and amendments which attempted to extend mortgage foreclosure continuances and redemption period extensions on a blanket basis to all mortgagors and to reduce or eliminate financial conditions upon a mortgagor's ability to remain in possession of the mortgaged land. ${ }^{94}$ These more expansive relief measures would

[1936]), and one case involving the transition between the 1935 and 1937 redemption period extension laws (Equitable Life Ins. Co. v. McNamara, 224 Iowa 859, 278 N.W. 910 [1938]).

94. (1) Deficiency Judgments: H.F. 78, 45th Iowa Gen. Assem., extra sess., 1933-34 (deficiency judgments abolished), 1933-34 Iowa House Journal 
have posed greater problems of constitutionality, but their rejection by the Senate also may have reflected a concern that relief be afforded with an eye toward both the worthiness of the mortgagor and the legitimate interests of the mortgagee.

Such concern for selectivity was more clearly manifested in the manner by which the "good cause" exception was construed and applied in the published opinions of the supreme court. By its initial adoption of a concept of "good cause" which focused on the farmer's ability to repay or refinance his debts, the court allowed foreclosures to proceed against farmers who would be unable to do either. Although the court once suggested that this approach was constitutionally required, it eventually honored later legislative directions placing insolvency of

312-13 (passed 94-4); H.F. 1, 46th Iowa Gen. Assem., reg. sess., 1935 (deficiency judgments abolished), 1935 Iowa House Journal 281-82 (passed 1023), 1935 Iowa Senate Journal 729-30 (failed to pass, 25-24); H.F. 120, 46th Iowa Gen. Assem., reg. sess., 1935 (no deficiency judgment unless mortgagee rebuts presumption that value of land equal to amount of debt, with mortgagor entitled to demand that value be determined by a jury), 1935 Iowa House Journal 282-83 (passed 105-0); H.F. 99, 47th Iowa Gen. Assem., 1937 (deficiency judgments abolished), 1937 Iowa House Journal 340-41 (passed 95-5). (2) Land Contracts: H.F. 314, 45th Iowa Gen. Assem., reg. sess., 1933 (change of contract forfeiture period from 30 days to between 15 and 280 days depending on percentage of purchase price paid by vendee), 1933 Iowa House Journal 1119-20 (passed 93-0); H.F. 278, 46th Iowa Gen. Assem., reg. sess., 1935 (expansion of 1935 redemption period extension law to include foreclosures of a vendor's lien), 1935 Iowa House Journal 961 (passed 95-0); H.F. 219, 47th Iowa Gen. Assem., 1937 (land contract foreclosure continuances and forfeiture abatement), 1937 Iowa House Journal 433-34 (passed 91-8). (3) Continuances and Extensions: H.F. 564, 45th Iowa Gen. Assem., reg. sess., 1933 (all foreclosure proceedings continued unless waste committed, with income apportionment by three-person arbitration committee), 1933 Iowa House Journal 1106-7 (passed 94-11); H.F. 350, 45th Iowa Gen. Assem., reg. sess., 1933 (under original version of 1933 redemption period extension law, extension automatic and not subject to good cause exception), 1933 Iowa Senate Journal 673-74 (adoption of amendment requiring application for extension and establishing good cause exception); H.F. 83, 45th Iowa Gen. Assem., extra sess., 1933-34 (all foreclosure proceedings continued unless waste committed, with income apportionment by three-person arbitration committee), 1933-34 Iowa House Journal 355-56 (income apportionment made optional and bill passed 87-0); H.F. 341, 45th Iowa Gen. Assem., extra sess., 1933-34 (deletion of good cause exception from 1933 redemption period extension law), 1933-34 Iowa House Journal 1338-39 (passed 76-30); H.F. 15, 46th Iowa Gen. Assem., reg. sess., 1935 (repeal of 1934 enactment limiting continuances to mortgages executed before 1 January 1934), 1935 Iowa House Journal 1084-85 (passed 75-3). 
the mortgagor and insufficiency of the mortgaged land beyond the ambit of "good cause." ${ }^{\prime 95}$

Thus, the overall characteristics of mortgagor relief legislation in Iowa during the Great Depression are somewhat conflicting. On the one hand, such legislation represented a rather dramatic response to the problems of financially distressed farmers that probably would not have been upheld in the absence of a change in the prevailing constitutional norms of contract impairment. On the other hand, such response did not materialize until financial distress had extended to conservatively financed farmers, and even then was construed to exclude farmers with overwhelming indebtedness. Iowa did not hesitate to intervene to protect its farmers from truly aberrant economic circumstances, but it refused to countermand the operation of more normal market forces. ${ }^{96}$ In this regard, Iowa farm mortgagor relief legislation was quite consistent with the general thrust of most of the agricultural programs implemented by the federal government during the New Deal. ${ }^{97}$

\section{ALMOST A HALF CENTURY after the Great Depression,} Iowa farmers went through another great cycle of economic boom and bust. ${ }^{98}$ Beginning in the mid-1970s, rising farm

95. Compare John Hancock Mut. Life Ins. Co. v. Schlosser, 222 Iowa 447, 450, 269 N.W. 435, 436 (1936), with Metropolitan Life Ins. Co. v. Henderson, 224 Iowa 1238, 278 N.W. 621 (1938).

96. For a contemporary recognition of this dimension of federal and state farm mortgagor relief measures during the Great Depression, see William G. Murray, Refinancing Farm Mortgages in Iowa (Ames, 1933), 30. "Those farmers who bought land at high prices during the boom years, 1919-1920, and borrowed large amounts on mortgages to pay for it, have long since lost their farms.... The land owners in these cases for the most part gambled with high priced land, and lost. But today, among farmers in distress are those who paid down substantial sums in the purchase of their farms. If the 1926 price level returns they will have an equity in their land and no difficulty in meeting interest and principal payments. It is for the benefit of such farm owners as these that the refinancing program and measures postponing foreclosure judgments have been designed."

97. Saloutos, The American Farmer, 254-70; Ellis W. Hawley, "Comment," Annals of Iowa 47 (Fall 1983), 215.

98. For overviews of agricultural economic conditions in Iowa and the United States during the 1980 s, see James Schwab, The Farm Credit Crisis in Iowa (Iowa City, 1985), and David H. Harrington and Thomas A. Carlin, The U.S. Farm Sector: How Is It Weathering the 1980's (Washington, DC, 1987). 
product prices and the financial effects of a surging inflation triggered a sharp rise in farmland values and a substantial expansion of farm mortgage indebtedness. ${ }^{99}$ In the early 1980 s, a cessation of extreme inflation and an accompanying increase in both nominal and real interest rates precipitated a rapid decline of farmland values that lasted for five years and entailed a total depreciation of more than sixty percent. ${ }^{100}$

There are some significant differences between the economic circumstances of the 1980 s and those of the Great Depression. During the 1980 s relatively more farmers were carrying relatively larger debts, and both the extent and rate of the decline in farmland values were greater. ${ }^{101}$ On the other hand, farm mortgage foreclosures were not as widespread, the nation's financial system was quite strong, a number of federal and state programs were in place to ameliorate some of the social effects of farm financial distress, and a substantial degree of prosperity existed in the rest of society. Nevertheless, there are some striking parallels between the farm mortgagor relief legislation Iowa considered or enacted during the 1930s and the relief measures it enacted during the 1980s.

The General Assembly's responses to the mounting problems of farm mortgagors began in 1985 with the enactment of a revision of the permanent mortgage foreclosure continuance law that had been adopted at the end of the Great Depression. ${ }^{102}$ The revision limited the duration of a governor's declaration of an economic emergency to one year, and allowed the scope of the declaration to be restricted to farmland. An economic emergency declaration was issued by Governor Terry E. Branstad on October 1, 1985. ${ }^{103}$ Presumably because the essen-

99. Iowa Department of Agriculture and U.S. Department of Agriculture, 1987 Iowa Agricultural Statistics, 93.

100. 1986 Iowa Land Value Survey (Ames, 1987).

101. Compare 1986 Land Survey with table 1.

102. Ch. 250, 1985 Iowa Acts 520 (codified, as amended, at Iowa Code $\S 654.15$ (1987)). For analyses of the law prior to and after its revision in 1985 , see Timothy D. Benton, "Iowa's Mortgage Moratorium Statute: A Constitutional Analysis," Drake Law Review 33 (1983-1984), 303, and Frank A. Camp and Gregory S. Crespi, "The Iowa Foreclosure Moratorium Law of 1985: A Preliminary Analysis and Proposed Changes," Drake Law Review 35 (19851986), 545.

103. Executive Order No. 20, VIII Iowa Admin. Bull. 1352, 12 February 1986. 
tial provisions of the law had been in place since 1939, there have been no reported instances of any challenges to the law's validity under the contract clauses of the federal or state constitutions. Also in 1985 the General Assembly enacted other measures facilitating consensual resolutions of farm mortgage difficulties and affording farm mortgagors a right of first refusal upon a state bank's disposition of farmland acquired through the enforcement of debts. ${ }^{104}$

In 1986 the General Assembly enacted a more elaborate program of farm mortgagor relief measures. Enforcement of any farm debt in excess of twenty thousand dollars was made subject to a temporarily effective system of mandatory mediation, and the amount of the exemption for farm machinery and equipment was raised from five to ten thousand dollars. Farmers received a right to cure mortgage defaults, and deficiency judgments resulting from the foreclosure of Farm Credit System mortgages potentially were subject to a delay in enforcement of up to five years. Farmers were afforded a restricted one-year right to redeem a homestead of up to forty acres for its fair market value, and Governor Branstad's 1985 declaration invoking the provisions of the mortgage foreclosure continuance law was extended by six months and expanded to include small businesses. ${ }^{105}$ During the next year the Iowa Supreme Court held that mandatory mediation was applicable to all

104. Ch. 252, $\S \S 34,42-47,1985$ Iowa Acts 524, 538-39, 540-43 (codified at Iowa Code §̧§ 524.910(2), 615.4, 628.26A, 628.29, 654.1, 654.18-.19 (1987)). The rights of a former owner to purchase farmland upon its disposition by a lender are analyzed in Thomas J. Houser, "A Comparative Study of the Former Owner's Right of First Refusal Upon a Lender's Resale of Foreclosed Agricultural Land: A New Form of State Mortgagor Relief Legislation," Journal of Corporation Law 13 (Spring 1988), 895.

105. Ch. 1214, $§ \S 7,10-12,14-29,1986$ Iowa Acts 323, 324-29 (codified, as amended, at Iowa Code §̧̧ 554.9501(6), 654.2A-.2C, 654A.1-.14, 656.8 (1987)); ch. 1216, §̧ 2-3, 6-9, 11-12, 1986 Iowa Acts 330, 330-33 (codified at Iowa Code $\S 627.6(11), 654.6,654.15-.16(1987))$. In contrast to the mandatory mediation scheme enacted in 1986, the efforts of the Farm Debt Advisory Committees during the 1930 s were entirely voluntary. An interesting parallel, however, is that the original version of the bills which evolved into the 1933 mortgage foreclosure continuance law would have established systems of mandatory mediation and binding arbitration. S.F. 170, 45th Iowa Gen. Assem., reg. sess., 1933 (mandatory mediation); H.F. 193, 45th Iowa Gen. Assem., reg. sess., 1933 (binding arbitration). 
pending foreclosure proceedings, and federal bankruptcy and district courts rejected contract clause challenges to the increased farm machinery exemption. ${ }^{106}$

In 1987 the General Assembly expanded the scope of a farmer's right of fair market value homestead redemption and extended it by an additional year in cases where the mortgaged land had been purchased by someone other than a national or state bank. The disposition of a homestead by a national bank was made subject to a one-year right of first refusal, and the General Assembly again extended the effectiveness of Governor Branstad's declaration under the mortgage foreclosure continuance law for an additional year. ${ }^{107}$

Meanwhile, under a farm bill enacted by Congress in 1985 , record levels of farm program benefits were being paid to Iowa farmers. ${ }^{108}$ Also, beginning in late 1986, farmers could file for relief under a newly enacted chapter of the federal bankruptcy code that included provisions paralleling major features of the Frazier-Lemke Acts of the 1930s. ${ }^{109}$ Furthermore, in late 1987 Congress enacted an Agricultural Credit Act under which mortgagors were afforded debt restructuring rights for loans held by the Farm Credit System and the Farmers Home Administration, and also repurchase rights upon the acquisition or disposition of farmland by such agencies. ${ }^{110}$

In late March 1988, the General Assembly again extended the effectiveness of Governor Branstad's 1985 mortgage fore-

106. First National Bank in Lenox v. Heimke, 407 N.W.2d 344 (Iowa 1987); In re Punke, 68 B.R. 936 (Bankr. N.D. Iowa 1987); In re Van Hove, 78 B.R. 917 (N.D. Iowa 1987).

107. Ch. 142, §̧ 4-5, 1987 Iowa Acts 196, 196-97 (codified at Iowa Code § 654.16 (Supp. 1987)); ch. 81, 1987 Iowa Acts 102.

108. Des Moines Register, 28 December 1986, 1A, 9 April 1988, 1A.

109. Bankruptcy Judges, United States Trustees, and Family Farmer Bankruptcy Act of 1986, Pub. L. No. 99-554, §§ 251-57, 100 Stat. 3088, 3104-16 (1986) (codified at 11 U.S.C.A. §̧ 1201-31 (West Supp. 1987)). For an evaluation of the new bankruptcy chapter's effects in its first year of operation, see Chris Faiferlick and Neil E. Harl, "The Chapter 12 Bankruptcy Experience in Iowa," Journal of Agricultural Taxation and Law 9 (Winter 1988), 302.

110. Agricultural Credit Act of 1987, Pub. L. No. 100-233, §§ 102, 108, 610, $614,615,101$ Stat. $1568,1574-79,1582-84,1669-73,1675-82$ (1988). For analyses of the effects of this legislation, see Neil D. Hamilton, Borrowers' Rights and the Agricultural Credit Act of 1987 (1988), and Farmers' Legal Action Group, Inc., Special Report on the Agricultural Credit Act of 1987 (1988). 
closure continuance declaration for another year. ${ }^{111}$ Three months later, the Iowa Supreme Court determined that a part of the retrospective effect of the 1987 expansion of a farmer's right of fair market value homestead redemption was invalid under the federal contract clause. ${ }^{112}$ The story of farm mortgagor relief legislation in Iowa during the 1980 s is not yet finished, and while it continues, the experiences of a half-century ago may be of special interest to Iowans.

111. Ch. 1017, 1988 Iowa Acts 14.

112. Federal Land Bank of Omaha v. Arnold, 426 N.W.2d 153 (Iowa 1988). 
Copyright of Annals of Iowa is the property of State of Iowa, by \& through the State Historical Society of Iowa and its content may not be copied or emailed to multiple sites or posted to a listserv without the copyright holder's express written permission. However, users may print, download, or email articles for individual use. 